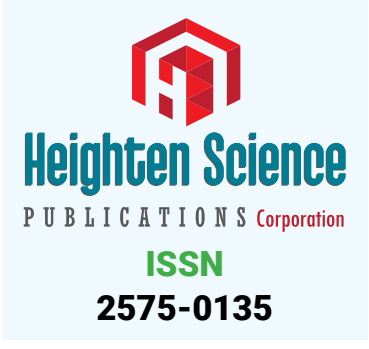

*Address for Correspondence: Soma Mondal, Division, Institute of Wood Science and Technology, Bangalore, Karnataka-560003, India Email:kumar.soma@yahoo.com

Submitted: 09 April 2019

Approved: 14 May 2019

Published: 15 May 2019

Copyright: () 2019 Mondal S, et al. This is an open access article distributed under the Creative Commons Attribution License, which permits unrestricted use, distribution, and reproduction in any medium, provided the original work is properly cited

Keywords: Clonal seed orchards; Fruit set; Flowering; Girdling; Prunning

Check for updates

\title{
Asynchronous flowering in clonal seed orchards - An effective strategy for alternative management
}

\author{
Soma Mondal ${ }^{1,2 *}$, Ashutosh Srivastava ${ }^{1}$, Geeta Joshi ${ }^{1}$ and HC \\ Yashavantha Rao ${ }^{3}$ \\ 'Department of Tree Improvement and Genetics, Institute of Wood Science and Technology, \\ Bengaluru, Karnataka-560003, India \\ ${ }^{2}$ Department of Studies in Microbiology, Manasagangotri, University of Mysore, Mysore, \\ Karnataka-570 006, India \\ ${ }^{3}$ Department of Biochemistry, Indian Institute of Science, Bengaluru, Karnataka-560012, India
}

\section{Abstract}

Tropical forests have long been of interest to biologists because of their high species diversity and their complicated patterns of community organization. The recent ecological studies which have demonstrated that tropical trees are diverse in their reproductive biology and dynamic population structure. Asynchronous flowering among the clones in a clonal seed orchard is an inherent problem resulting in poor seed and fruit set in them. These results in the complete defeat of the prime objective of establishment of clonal seed orchards (CSOs) i.e. abundant quality seed production poor flowering and asynchronous flowering between the clones are a major bottleneck in higher seed set in these clonal seed orchards across the country. Asynchrony found between clones may be attributed to the origin of clones, which are collected from different zonal populations as revealed by isoenzyme and DNA markers studies. This article reviews the work done in CSOs across the world and suggests an alternate strategy in designing the clonal seed orchards of the future.

\section{Introduction}

Asynchronous flowering in clonal seed orchards is one of the major challenges in tree improvement programs of various species. Asynchrony in flowering results in immensely denting major objective of establishment of CSOs i.e. mixing between various superior clones to produce quality seeds, understanding the phenomena of flowering pattern of the constituent clones becomes imperative to accomplish maximum synchrony [1]. It also results in non-representation of all the clones of the orchard in seed production leading to a drop in quality of seeds produced.

Seed orchards are the strong link between breeding programs and plantation establishment. They are designed and managed to produce seeds of superior genetic quality compared to those obtained from seed production areas, seed stands or unimproved stands will provide an advance generation of seed orchards by applying molecular markers technique [2]. The optimum goal of a seed orchard is achieved when the orchard population is under an idealized situation. The critical factor for the success of any a forestation activity is the availability of sufficient quantity of superior seeds. One of the tree improvement steps is the establishment of the CSOs which is a plantation raised by planting the vegetative propagated material (grafts, buds, cuttings) from the phenotypically superior individual in such a way that they produce high quality easily harvestable seeds and improved seeds from the orchards were used for afforestation [3]. 


\section{Genetic improvement}

The level of genetic diversity in seed orchards is important to plantation forests because high levels will increase resistance to pests, diseases, or climate change. Some of the clones in seed orchards that produced high numbers of female flowers did not mature to cones because of insect damage, physiological stress, or a lack of fertility synchronization. Since 1950, to improve seed production and genetic quality breeding populations and seed orchards have been used through the selected clones or progeny of elite trees, which have been isolated to reduce pollination from outside plantations [4]. Generally, clonal variation increased with increases in male flowering. However, if fewer clones produced a large proportion of the male flowers, genetic diversity decreased $[5,6]$. If a species is often wind-pollinated, a large amount of pollen will come from outside the seed orchard, widening the genetic diversity but decreasing the genetic gain. Strong genetic diversity in seed orchard crops can only be attained when all parents contribute similarly to the gamete pool, which virtually never occurs. Genetic improvement of Tectona grandis (teak) has been primarily focused on identification of superior trees from the diverse origin and their deployment in clonal Seed Orchards (CSO) to obtain seeds of high genetic quality in abundance [7]. Embryos from heavy seed are more heterozygous than the light seed. Seed grading may also have positive genetic consequences like the removal of excessive homozygosity from orchard crops. Seed grading by weight, size is known to improve germination growth, energy of seedlings and to facilitate the use of certain types of sowing equipment $[8,9]$. Unfortunately, flowering asynchrony and low fruit production have been a cardinal bottleneck in realizing benefits of CSOs. Over the period of time, a lot of efforts are made in order to formulate a comprehensive tree improvement strategy. As a result, Clonal Seed Orchards were established in Karnataka containing grafted plants from superior trees found in these localities and in other states.

Srivastava et al. [10], studied the variation in phenology of clonal seed orchard of Tectona grandis established by Karnataka Forest Department in Tittimatthi and evaluated the flowering pattern of the CSO on the basis of 'Overlap Index' which is an extension of Index of Similarity. In general, he found out that clones with higher overlap index were better yielders than those with low overlap index values. Clones of NGH (name of clones) series with low overlap index (0.154-0.173) recorded the lowest fruit yield (0.068-0.087 kg/tree). The TMT (name of clones) clone series, which had high overlap index (0.603-0.644) showed high seed yield (0.338-1.057 kg/tree). Flowering synchrony among clones of CSOs played an important role in assessing the genetic value of orchard crop. The rating an entire orchard for its relative degree of flowering synchronization adopting overlap index helped to track changes in flowering on a quantitative scale throughout the orchard life as well as in evaluating the panmixia/ genetic gain.

\section{Exploring the clonal seed orchards}

The first study using seed orchards were performed in 1934 using a vegetative production technique [11]. Since then, seed orchards have become an important global seed source by Zobel et al. [12]. El-Kassaby and Askew [13], reported that seed orchards may be established vegetative with grafts, cuttings, rooted cuttings or tissue culture plantlets propagated from a selected tree or with seedlings produced from seeds of the selected parent. Grafting is particularly useful for species where flowering is delayed, as grafts retain the physiological age of the parents. The first experimental clonal seed orchard of teak was established at the New Forest campus of the Forest Research Institute, Dehra Dun [14].

Seed orchard raised from selected clones propagated by grafting, cutting, airlayering. vegetative propagation by grafting has been suggested as a possible method for raising plants for the establishment of teak seed orchards. This technique has been 
standardized in teak on the basis of recommendations from Kedarnath and Mathew [15], about 1000 ha of Clonal Seed Orchard of teak were established in the country and since then they are the focus of tree improvement work in India.Seed orchards play an important role in bridging this gap by providing quality seeds in sufficient quantity. However, a lower seed set of these breeding populations is a major concern for forest managers. Fruit production varied among clones, selection of clones that flower during the peak flowering period may improve fruit production and treatments to delay the flowering period. The asynchronous flowering of constituent clones has been an important reason for lower fruit set in several tropical trees [16,17] and temperate timber species, any kind of factor that affects the orchards seed production would be a restraint for logical end of tree improvement programmes [18].

Manipulation of flowering is one of the main strategies to achieve flowering synchrony and to manipulate the sex of plants [19]. Flowering tree species can be manipulated through different treatments like cultural or hormonal treatments as well as the combination from these two methods of treatment. Several researchers have studied the induction of flowering, synchronization of the flowering period through hormonal, cultural and their combinations for temperate species [20]. Virtually there are no such studies have been made on tropical trees species except in Eucalyptus were able to increase the bud crop in the same year but in the next growing season in E. globulus using the trunk injection method [21].

Rawat et al. [22], observed asynchronous flowering in teak CSOs established at Forest Research Institute (FRI), Dehradun, India which was asynchronous and may result in lower fruit production in seed orchards. Variation in flowering phenology in a clonal seed orchard of teak was studied by [23]. They found asynchronous flowering and two distinct episodic peaks of flowering initiation (May to July and July to August). It was also evident from their study that clones from central and southern provenances of Karnataka were early to initiate bud swell.

Application of hormones to alter the physiology of the tree is an interesting area to be probed. In recentyears, the application of hormones to meet the needs of the researcher has gained momentum. Pharis et al. 1987, used the application of gibberellic acid 4/7 to induce flowering in Pinaceae members. Earlier attempts to induce flowering in teak using fertilizers and insecticides have not yielded encouraging results. A positive effect of fertilization on teak growth was also reported by other authors for plantations of intermediate ages, slightly younger or older than the 6-year-old plantation [24,25]. Smith [26], reported that spraying of Paclobutrazol on Peciamariana showed positive results in both male and female trees. Heitherington et al. [27], found that stem injection of Paclobutrazol resulted in a significant increase in a number of flower buds per meter shoot samples.

In a study carried out by Srivastava [28], it has been reported that application of Paclobutrazol has induced flowering in mature but non-flowering clones and promoted flowering among low-flowering teak clones. The use of Paclobutrazol in the form of soil drenching was found to be an effective, practical and safe way to increase the seed production in Clonal Seed Orchards of teak.

\section{Method to improve flowering in clonal seed orchards}

Seed orchards have been established in many countries to produce improved seeds. Methods to improve flowering in Clonal Seed Orchards is designed to ensure that a good mixture of the clone is achieved. Clonal seed bank should be established where the long-term future of the planting is secure. They should include a very broad range of genotype both geographically and genetically. They plant should be virus free, well documented and clearly labeled. By treating with Hormones, Root pruning (Figure 1), stem girdling (Figures 2,3), and branch girdling we can improve the Clonal Seed 
Productivity. Sweet [29], reported that application of micronutrients might stimulate flowering. The decision whether to use seedling seed orchards or clonal as well as poly cross seed orchards must be made on the basis of economic and genetic considerations [30]. Wong [31], found that girdling of branches of Gmelina arborea followed by Etheral treatment improved the flowering in 8.5 years old plantation. Potassium nitrate $1 \%$ is widely suggested for foliar spray just before the initiation of flowering. Other silvicultural techniques include root pruning and setting up of bee hive to ensure effective pollen movement. Selection of clones from nearby provenances has been suggested and a large of number of reports in temperate species is available, which document asynchronous flowering among the clones in a seed orchard, especially among monoecious species Gunaga [32].

\section{Conclusion and Recommendations}

Our study in various Clonal Seed Orchard reveals that, there is a large inter-clone difference in the flowering phenology as assist through a time of peak flowering. It is clearly evident from our study that the clones belonging to similar agro-climatic zones flower at the same time and produce higher seed yields. Therefore, it is highly recommended that,during stabilizing the Clonal Seed Orchard pulling of the clones should be done in the native agro-climatic zone involving the best clones of that area.

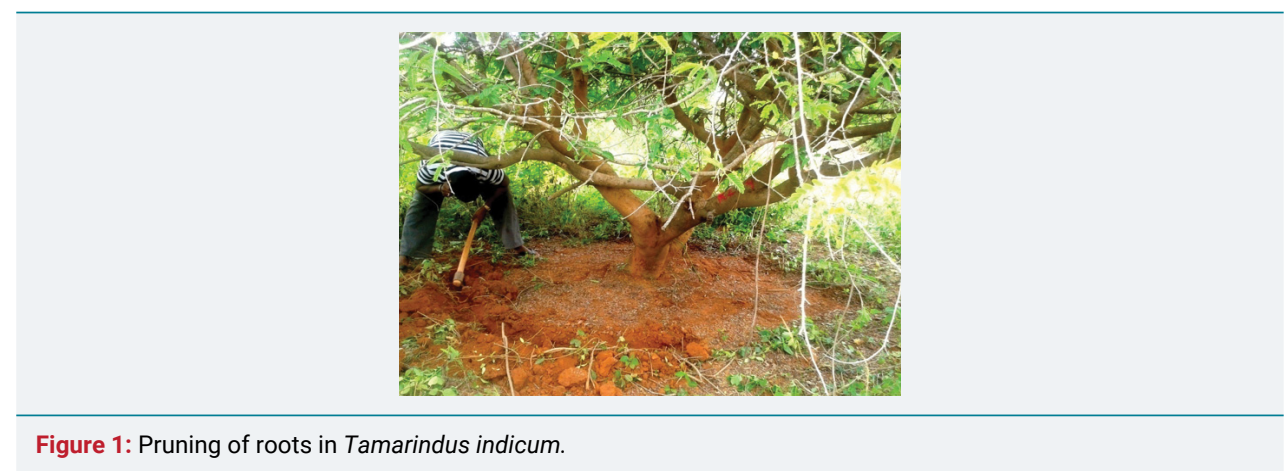

Figure 2: Girdling of shoots Tamarindus indicum.

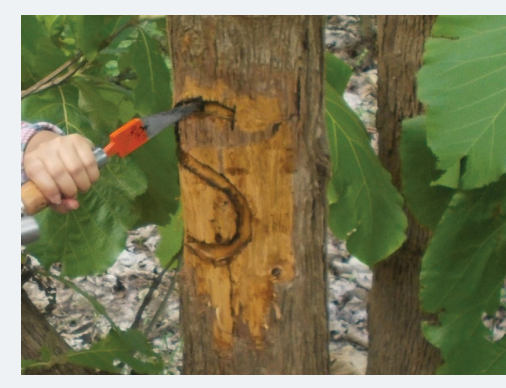

Figure 3: Girdling of shoots of Tectona grandis. 


\section{Acknowledgment}

Authors are thankful to Mr. Surendra Kumar, Indian Forest Service, Director, Institute of Wood Science and Technology, Malleshwaram, Bangalore for constant support and encouragement.

\section{References}

1. Sett R, Mishra JP, Rana PK. Seed production of teak in different orchards of central India: the present scenario. Int J Sci, EnvironTechnol. 2016; 5: 969-990. Ref.: https://tinyurl.com/y6rnagov

2. Yuan H, Niu S, El-Kassaby YA, Li Y, Li W. Simple Genetic Distance-Optimized Field Deployments for Clonal Seed Orchards Based on Microsatellite Markers: As a Case of Chinese Pine Seed Orchard. PLoS ONE. 2016; 11: e0157646. Ref.: https://tinyurl.com/y5pfk6v3

3. Zhang $\mathrm{HX}$, Shen $\mathrm{XH}$. Progress on reproductive system of forest seed orchards. Scientia Silvae Sinicae. 2002; 38: 129-134. Ref.: https://tinyurl.com/yyarmcyx

4. Ertekin M. The Molecular Basis of Plant Genetic Diversity. In: Genetic Diversity of Seed Orchard Crops. 2012. Ref.: https://tinyurl.com/yymz27f8

5. Burczyk J, Chalupka W. Flowering and cone production variability and its effect on parental balance in a Scots pine clonal seed orchard. Annales des sciences forestières, INRA/EDP Sciences. 1997; 54 129-144. Ref.: https://tinyurl.com/yyw3982z

6. Krishna $\mathrm{H}$, Alizadeh $\mathrm{M}$, Singh $\mathrm{D}$, Singh $\mathrm{U}$, Chauhan $\mathrm{N}$, et al. Somaclonal variations and their applications in horticultural crops improvement. 3 Biotech. 2016; 6: 54. Ref.: https://tinyurl.com/y489a6hj

7. Szmidt AE. Genetic composition of seed orchard crops. Forest Ecology and Management. 1987; 19: 227-232. Ref.: https://tinyurl.com/y4z2c5n9

8. Larsen CS. Genetics in Silviculture. Oliver and Boyd, Edinburgh, Scotland. 1956; 224. Ref.: https://tinyurl.com/y2obvk98

9. Werner M. Effects on plant yield, height growth and height variation in fractionation of a grain seed lot (Effects of spruce seed grading on plant percent, height growth and variation). Inf. Skogsforad. Institute for skogsforbattring, Ekebo.1976; 4.

10. Srivastava A, Devagiri GM, Gunaga RP, Vasudeva R, Rathore TS, et al. Induction of flowering in teak clonal seed orchard-a case study. Indian J Trop. 2008; 16; 33-42.

11. Larsen CS. Genetics in Silviculture, Oliver \& Boyd, Edinburgh, Scotland. 1956, 224. Ref.: https://tinyurl.com/y2obvk98

12. Zobel BJ, Barber J, Brown CL, Perry TO. Seed orchards; their concept and management. J Tropical Forest. 1958; 56: 815-825. Ref.: https://tinyurl.com/yyaevukv

13. El-Kassaby YA, Askew GR. Seed orchards and their genetics. In: Mandal AK, Gibson GL. (Ed.), Forest genetics and tree breeding, CBS Publishers and Distributors. Daryaganj. New Delhi. India. 1998; 103-111.

14. Kumaravelu G. Teak in India. In Henry Wood (ed.) Teak in Asia, FORSPA Publication. No. 4, Bangkok. $1993 ; 27-34$

15. Kedharnath S, Matthews JD. Improvement of teak by selection and breeding. Ind For. 1962; 88: 277-284. Ref.: https://tinyurl.com/y5r294fb

16. Palupi ER, Owens JN. Reproductive phenology and reproductive success of teak (Tectonagrandis) Int J Plant Science. 1998; 159: 833-842. Ref.: https://tinyurl.com/yy8dg8sv

17. Gunga RP. Genetic variation for phenology in a clonal seed orchard of teak. A thesis submitted to Department of Forest Biology and Tree improvement college of Forestry, Sirsi. 2000.

18. Griffin AR. Clonal variation in Radiata pine seed orchards. II. Flowering phenology. Aus Forest Res. 1984; 14: 271-281. Ref.: https://tinyurl.com/y2bjqml4

19. Gunaga RP. Flowering in seed orchards: Pattern, consequences and of flowering. Seminar report of the Master of Science in Forestry, submitted to the Dept. of Forest Biology and Tree Improvement, College of Forestry Sirsi. 1999; 35.

20. Pharis RP, Tomchuk D, Beall FD, Rauter RM. Promotion of flowering in white spruce (Piceaglauca) by gibberellin $A 4 / 7$, auxin (naphthaleneacetic acid), and the adjunct cultural treatments of girdling and Ca(NO3)2 fertilization. Canadian J Forest Research. 1986; 16: 340-345. Ref.: https://tinyurl.com/y25f8esy 
21. Hetherington. Management of Eucalypt seed orchard with pacloburtrazol. in: proc of Australian forest growers conference on. Faces of farm forestry. Launceston. Tasmania. 1992; 235-238.

22. Rawat MS, Uniyal DP, Vakshasya RK. Variation in the model teak seed orchard. New Forest, Dehra Dun. Ind J For. 1992, 118: 60-65. Ref.: https://tinyurl.com/yy27fden

23. Gunaga RP, Vasudeva R. Variation in flowering phenology in a clonal seed orchard of teak. J Tree Sci. 2002b; 21: 1-10. Ref.:

24. Neelayv R, Bhandari RS, Negi KS. Effect of insecticidal and hormonal spray on the production of fruits in teak seed orchards. Ind For. 1983; 109: 829-837. Ref.: https://tinyurl.com/yxp2mrys

25. Pharis RP, Tomchuk D, Beall FD, Rauter RM. Promotion of flowering in white spruce (Piceaglauca) by gibberellin A4/7, auxin (naphthaleneacetic acid), and the adjunct cultural treatments of girdling and $\mathrm{Ca}(\mathrm{NO3}) 2$ fertilization. Canadian J Forest Research. 1986; 16: 340-345. Ref.: https://tinyurl.com/y25f8esy

26. Smith RF. Effects of stem injections of gibberellins $A(4 / 7)$ and paclobutrazol on sex expression and the within-crown distribution of seed and pollen cones in black spruce (Piceamariana). Canadian $\mathrm{J}$ Forest Research. 1998; 28: 641-651. Ref.: https://tinyurl.com/y2xpulah

27. Hetherington S, Jones KM, Koen TB. Stimulation of bud production in Eucalyptus globulus by paclobutrazol application. In Proceedings: IUFRO Symposium on Intensive Forestry: The role of Eucalypts, Durban, South Africa. (Ed) APG Schonau. 1991;1:39-41. Ref.: https://tinyurl.com/yymgmkvp

28. Srivastava A. Quantitative analysis of variation for flowering phonology and fruit yield in a Clonal Seed Orchard of Teak. Ind J Tropical Biodiversity. 2013; 16: 143-154.

29. Sweet GB. Seed orchards in development. Tree Physiol. 1994; 15: 527-530. Ref.: https://tinyurl.com/y2ajazzs

30. Baradat P. Durel CE, Pastuszka P. The polycross seed orchard: an original concept. In Proc. AFOCEL/ IUFRO Conference, Bordeaux. France. 1992; 1: 181-188.

31. Wong CY. Flower stimulation techniques for mature Gmelina arborea Roxb. Trees. Malaysian Forester. 1987; 50: 79-86. Ref.: https://tinyurl.com/y3mty8nj

32. Gunaga RP. Genetic Variation for Phenology in a Clonal Seed Orchards of Teak (TectonagrandisLinn.f) M.Sc. Forestry Thesis, Department of Forest Biology and Tree Improvement, College of Forestry, Sirsi campus, University of Agricultural Sciences Dharwad: 2000; 128. 